\begin{tabular}{|c|c|c|}
\hline Received: March 2019 & Accepted: April 2019 & Published: April 2019 \\
\hline \multicolumn{2}{|c|}{ Article DOI: http://dx.doi.org/10.24903/sj.v4i1.271 } \\
\hline
\end{tabular}

\title{
Bilingual Education In Indonesia: Between Idealism and the Reality
}

\author{
Dwi Jayanti \\ UIN Syarif Hidayatullah Jakarta \\ dwijayanti230@gmail.com \\ Anton Sujarwo \\ UIN Syarif Hidayatullah Jakarta \\ antonrakan@gmail.com
}

\begin{abstract}
Today English plays an important role in the development of education. In response to advances and develops the education in this globalization era, English bridges communication among people around the world. The ability to communicate in English becomes crucial. The development in education as an impact of globalization significantly influence the English teaching and learning concept. Bilingual education becomes necessary, it can stimulate the cognitive ability especially on cognitive function, it can also motivate the bilingual program. Education as a conscious effort to build and develop the quality of human resources and one popular education system promote bilingual education becomes a choice by parents. Using bilingual education become popular and be needed. Indonesian educational policies see this phenomenon as a new modern solution to be practiced in Indonesia's education system for many years. The purpose of writing this library research article paper is to elaborate and give understanding about bilingual education in Indonesia for certain time. The article start with the differences between bilingual and bilingualism, the relation of the bilingual process with executive function, the practice of bilingual education in Indonesia compared by the national standardized school, the challenges and solutions concerning the policy and practices in language teaching and learning focused on bilingual education in Indonesia. The present article employ a descriptive qualitative approach from reputable references which is relevant to the topics.
\end{abstract}

Keywords: bilingual, bilingualism, cognitive development, executive function, bilingual education in Indonesia 


\section{INTRODUCTION}

The growth in science and technology as an impact of globalization greatly influence the concept of English teaching and learning process. One of the most popular methods nowadays is using bilingual education. Indonesia as one of developing country makes an effort to face the global competition in which English considered as one of the important factors by increasing the quality of education through implementing bilingual program.

In some countries, this program become crucial to implemented as well as in Indonesia. However, in reality the implementation of bilingual program in Indonesia seems to be hard where there are many problems arise during the program. One of them is that the government of Indonesia should prepare professional bilingual teachers, also the programs needs a lot of money to implemented. Moreover, the bilingual class and the students are exclusively treated in terms of school facilities, academic issues, supporting the program like sister school compared to regular class students or national standardized school. The implementation of international standard school in Indonesia is very challenging.

For these reasons, this research paper discusses how far the effectiveness of bilingual education implemented in Indonesia as well as the concept of bilingualism, the influenced bilingualism on executive function, the practice of bilingual education in Indonesia and how far the challenges and solutions concerning the policy and practises in language teaching and learning in the field.

Furthermore, this reseach paper is intended to give picture of some factors influencing the failure of bilingual programs in Indonesia as it is indicated that the goverment of Indonesia only apply the bilingual program for national standard schools for six years because of many problems and obstacles in the implementation.

Through this research paper as well, the government should aware that the degrees of students competencies in Indonesia are such heterogeneous so that generalizing the bilingual program for most of national standard school with different facilities in Indonesia is not effective.

\section{Bilingualism}

Discussing bilingualism, according to Walner (2016), bilingualism is the ability to communicate fluently in a language other than your native language. Bilingualism is complex and multi-dimension phenomena. The process of bilingualism involves several factors that make the bilingual experience deeply heterogeneous and potentially alter its consequences 
(Bialystok, 2008). The definition of bilingualism does not come with the same ideas, but it can be assessed along a continuum of the level of skill development and the frequency of use of the language. It is related to social, psychological, and linguistic phenomena and needs to be understood from a multidimensional aspect.

Following these facts, There are many different interpretations of the definition of bilingualism among researchers and educators as it depends on which we approach this phenomenon. This question also has been tried to be answered by other researchers, Grosjean (1998) defines that bilingualism is regular use of two languages, according to Haugen (1953) says that bilingualism is an individual condition when he or she starts to own the ability to create meaningful statements in two languages.

In terms of proficiency in acquiring two languages, equal proficiency in both the native and second language is usually uncommon. Typically, when an individual has an increased proficiency in one language compared to the other, we called unbalanced bilingualism, it is the most common type. However, it is important to say the native language is not always stronger than their new language. Based on Owens, an individual can become more fluently in their newly learned language than their native language if they rarely use their native language (Owens, 2012). To sum up, the proficiency and fluently are depend on how much their interaction with the language.

Bilingualism and bilingual as a consequence of interaction among people overseas which has advantages and disadvantage impact through a community both individually and socially in the world. It is interesting to see that both bilingualism and bilingual have become a phenomenon since ancient times for educators and researchers. Both of them influence people from early childhood to adulthood consciously and unconsciously.

\section{Bilingual}

People can become bilingual anywhere and for many reasons. One of the popular ones is due to cultural mixing among two immigrants such as states that are closer to Mexico have increased Spanish-English bilingual populations than states further from Mexico (Walner, 2016). This experience mostly happens in America, but we can also become bilingual with simultaneous efforts and practice of the language at home or our schools or even our environment. Bilingualism also can be experienced from childhood toward adolescence. These phenomena lead linguists to try to define what precisely bilingual means because this phenomenon seems unique and complicated. 
Definition about bilinguals varies from Bloomfield (1995) to Grosjean (1998) following the context and situation. However, we can say simply that bilingual is a person or individual who is proficient to be able to speak two (or more) languages at a certain level (Grosjean,1995). .

According to Serra there are three types of bilinguals referring to the kinds of bilingualism. The first is planned bilingual, secondly natural bilingual and the third is adult bilingual (Serra, 2017).

Planned bilingual is those who achieve their languages because of planned strategy that parents normally decide. They can decide to follow various strategy, but the more natural it is the more successful the bilingualism will be and early bilingualism has also some benefits.

The second is natural bilingual and this group refers to the person who was born in a place that naturally offers many languages. Some of these regions are a consequence of historical conflict, most of the time, even connected to politics.

The third is adult bilingual. This last group includes all those people who need to move to a foreign country and learn new language, it could be for work or any other reason, at a late stage of life (Serra, 2017) and the terms of language used by bilinguals which influence each other is the first language (L1) and second language (L2) (Serra, 2017).

However, even there are too many kinds of bilinguals, bilinguals know their languages to the level that they need them. Some bilinguals are dominant in one language, others do not know how to read and write one of their languages, others have only passive knowledge of a language and, finally, a small minority, have equal and perfect fluency in their languages. What is important to keep in mind is that bilinguals are very diverse, as are monolinguals (Grosjean, 1998).

\section{Bilingual And Executive Function}

Executive function is a set of mental processes that helps us connect past experience with present action. People use it to perform activities such as planning, organizing, strategizing, paying attention to and remembering details and managing time and space. Based on Chan, these are skills and processes each of us use every day to make plans, keep track of time and finish work on time, keep track of more than one thing at once, engage in group dynamics, meaningfully include past knowledge in discussions, evaluate ideas and 
reflect on our work, also ask for help or seek more information when we need it (Chan et.al, 2008).

Many years linguists and researchers have questioned and investigated the correlation between bilingualism and executive function. Started from the research taken about 50 years ago there was a popular assumption and scientific evidence that concluded exposing children to more than one language was a potentially dangerous experience for them. The presumption is that children will display "mental confusion" and show signs of "mental retardation." This view was finally challenged by a study by Peal and Lambert in Bialystok (2015) which English-French and English-bilingual monolingual children conducted a series of tests. The researchers estimate that monolingual and bilingual children will be equivalent on measures of nonverbal intelligence but bilingual will get a lower score on verbal intelligence. To their surprise, the results of the tests bilingual children outperformed their monolingual peers in the entire set of tests, including nonverbal intelligence. In contrast to the previous description, Peal and Lambert argued that bilingual children showed they enhanced in "mental flexibility", perhaps as a consequence of having to switch between languages (Bialystok, 2015).

At present, the view of bilingualism has changed because of the development of modern scientific knowledge. During the second period, the language was seen by researchers and educators as an interference such as barriers to children's academic and intellectual development. The interference is more beneficial than defects. This is accepted as a kind of training for the brain. The brain is in constant conflict and is challenged to resolve internal conflicts. This mind exercise significantly strengthens the cognitive muscles of the brain (Chilla, Solveig et all, 2010).

Another study had shown that bilingual is more proficient than monolingual in solving several types of mental puzzles. Psychologists Ellen Bialystok and Michelle MartinRhee tried to prove this in a survey. They ask for bilingual and monolingual preschoolers to sort objects of various shapes and colors. The first task is relatively easy, but when tasks become more challenging, bilingual is faster (Matter, 2012).

\section{The Practice of Bilingual Education in Indonesia}

In recent time, the world has been changing in many aspects. This description indicates that the changes involve almost all aspect of life and sectors in the world, to face this globalization we have to increase competitive skills, moreover increase the 
communicative competencies, especially in English as accepted in the world as an international language. This communicative competence refers to knowing the language and the skills needed to use language in real life situation for fulfilling communicative needs (Ahmed, 2018).

As the effect of the paradigm on Indonesian educational contexts due to the importance of English as the international language in the globalization era, also the consciousness of how important benefit of being bilingual especially in enhancing brain's executive function, the Indonesian government via the Ministry of National Education make an effort to establish a new concept educational programs that will maximize the competencies in the target language specifically English. Indonesia government has been establishing a bilingual school as one of the innovative efforts to deal with the above issue with the final target those bilingual school can be a RSBI or SBI school. RSBI (Rintisan Sekolah Bertaraf Internasional) and SBI (Sekolah Bertaraf International) defined as the Pioneer International Standard Schools. Where is the programs which are advocated to be implemented in elementary school, secondary school and high school (Margana, 2015).

The implementation of the bilingual program above refers to the Acts of the Indonesian Republic Number 2 Year 2003 Article 50 Verse 3. The act advocates that the Indonesian government and the local government have to organize at least a unit of education to be developed further as a unit having international standards of education at all levels of education. Another law umbrella of its programs is also Government Rules Number 17 the year 2010 about the school management.

The Acts of National Education System also mentioned that the National Education System should accommodate the capability to giving a guarantee the Indonesian citizen to get an even opportunity in education study and practices, the quality improvement and the competencies of education to face the local, national and international lives.

Bilingual program in Indonesia started in 2004, it is completed the previous school program that has already adopted similar programs that applied in private school. Bilingual programs in Indonesia applied national curriculum with international programs as an additional program, English as a means of classroom communication and the implementation of using it in some selected subjects, mathematics and natural science for example, and other subject using Bahasa in classroom activity.

More specifically, English as a means of classroom communication that is used and practiced by the bilingual teachers of the selected subjects able to facilitate bilingual students 
to be accustomed to the use of English in educational contexts which could generate bilingual mind on the part of students. It gives benefit for them as they have meaningful English learning process to deal with the English materials of selected subjects classroom communication practices. The use of the two languages packed in bilingual education program strengthens the concept of the meaning of the subjects learned and establishes automatic translating systems in the learners' brain (Romaine, 1995)

Regarding the progress, the implementation of the bilingual education officially started in Indonesia in 2004 become more popular in 2006 and gained its popularity for about six years establishing 1400 schools categorized as international standardized schools in 2012.

The Growth of Bilingual School in Indonesia Every Year

\begin{tabular}{|lccccc|}
\hline School & $\mathbf{2 0 0 6}$ & $\mathbf{2 0 0 7}$ & $\mathbf{2 0 0 8}$ & $\mathbf{2 0 0 9}$ & $\mathbf{2 0 1 0}$ \\
\hline Elementary & 25 & 38 & 66 & 66 & 33 \\
\hline Junior & & 102 & 102 & 94 & 94 \\
\hline Senior & 100 & 100 & & 121 & 93 \\
\hline Vocational & & 179 & 74 & 42 & 138 \\
\hline Total & $\mathbf{1 2 5}$ & $\mathbf{4 1 9}$ & $\mathbf{2 4 2}$ & $\mathbf{3 2 3}$ & $\mathbf{3 0 8}$ \\
\hline
\end{tabular}

Source: Ministry of National Education Published by Diskominfo (Ministry of Communication and Informatics) in 2012

\section{Bilingual Vs National Standardized School}

A concrete definition of bilingual education is stated by Cohen saying that bilingual education is the use of more than one language as media of instruction for a student or a group of students in part or all of the school curriculum (Cohen, 1976). Bilingual education scholars also believe that language and culture is impossible to be separated, therefore, as language is the basis of any culture, a very strong factor of bilingual education is bicultural education and learning a language is also learning about a certain culture (Buschenhofen, 1980)

Indonesia's bilingual program has become a significant breakthrough, encouraging the use of English in non-English subjects (known as subjects across the curriculum) (Santoso, 2006). Such a program is made for having a high-quality education which can be competitive worldwide. Before officially being pointed as SBI, the school must fulfill the standard required for RSBI and National Regular School of Indonesia. 
There are eight standards required for the regular school of Indonesia; standard of content, qualification of output, teaching and administration staff, infrastructures, management, finance and assessment (Departemen Pendidikan Nasional, 2006). These eight standard is called SNP (Standar Nasional Pendidikan). The school which has fulfilled the eight standards is then named SSN (Sekolah Standard Nasional).

The Qualification of Bilingual School and National Standardized School in Indonesia.

\begin{tabular}{|c|c|c|}
\hline Parameter & Bilingual School & $\begin{array}{c}\text { National Standardized } \\
\text { School }\end{array}$ \\
\hline $\begin{array}{l}\text { SNP (Education } \\
\text { National Standard) } \\
\text { Teacher categorized }\end{array}$ & $\begin{array}{l}\text { Fulfilled } \\
\text { Min S2/S3: 10\% (SD), } 20 \% \text { (SMP), } \\
30 \%(\mathrm{SMA} / \mathrm{K})\end{array}$ & $\begin{array}{l}\text { Fulfilled } \\
\text { Min S1, There is no } \\
\text { requirements for S2/S3 }\end{array}$ \\
\hline $\begin{array}{l}\text { Principal } \\
\text { Accreditation } \\
\text { Facilities }\end{array}$ & $\begin{array}{l}\text { Min S2 and English active } \\
\text { A (95) } \\
\text { The computerized system, National } \\
\text { Curriculum with additional } \\
\text { International Programs, Applied } \\
\text { SKS in SMA/K }\end{array}$ & $\begin{array}{l}\text { Min S1 } \\
\text { Min B } \\
\text { National } \\
\text { Computerized } \\
\text { additional }\end{array}$ \\
\hline Teaching & $\begin{array}{l}\text { Computer-based; Using English } \\
\text { and Bahasa in a certain subject like } \\
\text { Science \& Math ISO } 9001 \text { and ISO } \\
14000\end{array}$ & $\begin{array}{l}\text { No Double shift and No } \\
\text { requirements for ISO / } \\
\text { international standard }\end{array}$ \\
\hline Evaluation & $\begin{array}{l}\text { Applied National Exam (UN) } \\
\text { Minimum score } 7.0 \text { for RSBI and } \\
8.0 \text { for SBI enrichment with } \\
\text { International exam system (Modern } \\
\text { country and or other developed } \\
\text { countries. }\end{array}$ & $\begin{array}{l}\text { Applied National Exam (UN) } \\
\text { with minimum score } 6,5\end{array}$ \\
\hline Graduates/ Output & $\begin{array}{l}\text { High qualified competencies and } \\
\text { English proficiency, ready to face } \\
\text { international competencies around } \\
\text { the world }\end{array}$ & High qualified competencies \\
\hline
\end{tabular}




\begin{tabular}{|ll|}
\hline Culture & Guarantee to give character mental Guarantee to give character \\
& $\begin{array}{l}\text { building, free from bullying, mental building, free from } \\
\text { democracy atmosphere, active bullying. } \\
\text { participation }\end{array}$ \\
\hline Funding & RAPN, RAPBD, $20 \%$ for students RAPN, RAPBD \\
& from low middle class subsidized, \\
& parents for private school \\
\hline
\end{tabular}

Source: Ministry of National Education Published by Diskominfo (Ministry of Communication and Informatics) in 2012

Based on the statistic above, it is evident that establishing English-Indonesian bilinguals education in Indonesia is great importance because it could facilitate Indonesian citizens to gain powerful mind to cope with any problems that they may encounter in the meaning-making of any social planes that exist in global contexts. This implies that all relevant parties need to consider the importance of establishing the English-Indonesian bilingual education in Indonesia. On the grounds that is justified by convincing and very urgent theories by reason of the English-Indonesian bilingual establishment can provide a large number of advantages in terms of cognitive development, language achievement processes, intercultural awareness, concept of mediation across-language and others.

To sum up, the establishment of English-Indonesian bilinguals is urgent to be conducted in Indonesia.

\section{The Challenges of Bilingual Education in Indonesia}

The bilingual school in Indonesia stay for its popular education program for about six years from 2006 to 2012. Since 2011 this program was criticized by some parties that argue such a program has many weaknesses and discriminated the low from the high class as those bilingual schools are mostly enjoyed by the high class than the low and create many strata and customization (Henly, 2013)

This program pointed as a program that spends a lot of money and designed only for certain class in certain school as categorized the bilingual school or pilot of international standard school. This condition builds the social gap and worse social atmosphere for some of part students and parents that feel their children are not evenly treated. Such a social gap and social jealousy growth become discrimination feeling (Margana, 2013).

Another problem is evident that the bilingual education program requires some professional bilingual teachers who are competent in the first language (Indonesian) and 
target language (English) to use the two languages as a means of classroom communication of selected subjects (Margana, 2015). This implies that the Indonesian government should prepare professional bilingual teachers before implementing programs. The main problem exists in Indonesia is that a great number of bilingual teachers have insufficient English proficiency to utilize English as a means of classroom instructions. The bilingual teacher finally only used English to do some opening, closing and instructional sentences in the classroom rather than explore the subject with suitable terms. Added to this, some bilingual teachers have little commitment to apply for the bilingual program. This drives some opponent parties to take the case into judicial review of the implementation of the bilingual class program. With regard to this, the Judicial Court came to the agreement that the bilingual program was against to the basic laws of Indonesian Republic Year 1945. As the bilingual class program has been only enjoyed by the rich, the implementation of the bilingual program is believed to generate the degradation of the nationality among the young generations in the sense that they are less proud of Indonesian as the national language (Nasional.kompas, 2011). Also, the label of the bilingual class program is believed to be a way of getting fund from the students' parents and other related parties which, to some extent, violates the policy of the compulsory education advocating that school fee of public elementary school to junior high school becomes the responsibility of the Indonesian government.

In other words, the bilingual class program has been banned to be carried out since January 2013 (Rakyat, 2013), in this case, National Ministry Education develop another curriculum as we know curriculum 2013 as a solution from this banned. State bilingual school slowly but sure following this policy put their position back, still, for some private school they keep the international curriculum and inserted on their school curriculum.

\section{FINDING AND DISCUSSION}

\section{Finding}

From this fact, we would say that the government of Indonesia have still found many obstacles and challenges in applying bilingual program as an effort to improve national standard school to become International standard ones with the curriculum which fit to the global needs, those challenges are:

- Since 2011, bilingual program was critized by some parties that argue such program has many weaknesses and discriminated the low from the high. 
- Bilingual school school are mostly enjoyed by the high class than the low and create many strata and customization.

- There are some discrimination between bilingual class and regular class in term of school facilities, academic issues, supporting program like sister school.

- Bilingual program tends to spend alot of money and designed only for certain class in certain school categorized as bilingual school.

- Bilingual programs build social gap and social jelousy among the students and their parents.

- Bilingual program requires some professional teachers who are aware of first language and target language to use as a mean of classroom communication for selected subjects.

- Alot of bilingual teachers do not have sufficient English proficiency to apply in bilingual classroom.

- Most bilingual teachers have a little commitment to apply their English toward the program.

In accordance with these problems, the government of Indonesia should develop alternative programs or curriculum that support Indonesian students in facing a global era such as curriculum 2013 which is initiated by Indonesia National Ministry of Education. Even applying bilingual program is not simple but it still has many advantages for bilingual individuals particularly on their executive function.

\section{Discussion}

This section discusses about the finding of the study. It is concerned about the effectiveness of applying bilingual program toward national standardized school that shows most of the application of bilingual programs toward national standard schools is not effective. It was proven by so many negative responses as well as research and data which gives negative effect and result of this program. For the next study, the researcher can find the best strategies to established the appropriate bilingual program in Indonesia.

\section{CONCLUSION}

The present paper gives summarizing about the concept of bilingualism and bilingual in many levels since the bilingual gives many benefits. The reviewed research examining the effect of bilingualism on people's cognitive development, in a specific part, executive function. Studies declared that bilingual advantages in various tasks are described with the 
purpose of identifying the process of executive function component that might be responsible for this bilingual advantage. Bilingual experience improves the brain's executive function, that refers to command system that directs the attention that we use for planning, problemsolving and many various mentally demanding task.

This paper also looks at how crucial English implemented in Indonesia, trying to settle in designing and applying one of bilingual education program RSBI and SBI as an International Standardized School to gain high qualified level and competent bilingual performance in their field to face global challenges. Communities responds are quite positive about bilingual school, and for some of them feel these programs are quite useful. This program has produced many bilingual schools that will enable them to create high-quality learners output, improve skill and language competence at the same time. When considering these some communities argument, another evidence shows that RSBI disproportionately serves middle and upper-income families ( $80 \%$ from these strata). This situation is contributed to many factors, a number of financial, social, and academic reasons more focus by government is needed to ensure low-income compliance regulations are met. Finally, suggestions are addressed to policymakers and stakeholders that preparing all the suitable aspect to bilingual education in Indonesia, i.e., infrastructure, academic, facilities, and human resources aspect as a base foundation to build strong bilingual education in Indonesia.

\section{BIBLIOGRAPHY}

Ahmed, S. (2018). Communicative competence in English as a foreign language: Its meaning and the Pedagogical Considerations for its development. The Creative Launcher, 2(6), 301-312.

Bialystok, E. (2008). Bilingualism : The Good, the bad, and the indifferent. Cambridge Journals, 12(1), 3.

Bialystok, E. (2015, June). Bilingualism and the Development of Executive Function: The Role of Attention. Child Development Perspective, 9(2), 117 - 121.

Bloomfield, L. (1995). Language (Revised Edition). London: Allen \& Unwin.

Buschenhofen. (1980). Trendy Experimentation Or Cultural Enrichment. Journal of Multilingual and Multicultural Development, 1(4), 303 - 312.

Chan, R., Shum, D., Touloupoulou, T., \& Chen. (2008). Assessment of Executive Function : Review of Instrument and Identification of Critical Issue. Archives of Clinical Neuropsychology, 23, 201 - 216.

Chilla, Solveig et all. (2010). Ezel : Kindliche Mehrsprachigkeit. Munchen: Storungen. 
Cohen, A.D., M.Swain. (1976). Bilingual Education: The Immersion Model in the North American Context. TESOL Journal, 10(1), 144.

Dewey, M. (2007). English as a lingua franca and globalization: an interconnected perspective. International Journal of Applied Linguistics, 17(3), 333.

Dictionary,O.E(2017). http://www.etymonline.com.

Grosjean, F. (1995). A Psycholinguistic Approach to Code-Switching of Guest Words by Bilinguals. Cambridge: Cambridge University Press.

Grosjean, F. (1998). Neurolinguist, Beware! The Bilingual is Not Two Monolinguals in One Person. Brain and Language, 36, 3 - 15.

Harding-Esch, E. a. (2003). Philip : The Bilingual Family. A Handbook for Parents. Cambridge.

Haugen, E. (1953). The Norwegian Language in America. Philadelphia: Pennsylvania Press.

Henly, J. W. (2013). Evaluation of International Standard School in Indonesia. Jakarta: Ministry of Education and Culture.

Kupelikilinc, Nicola/ Ringler, Maria. (2007). Spracherwerb von mehreren Sprachen In : Verband binationaler Familien und Partnerschaften. Kompetent Mehersprachig, 29 50 .

Margana. (2009). Developing Model of Bilingual Education at Vocational High School in Yogyakarta. Research Report of Competitive Grant Funded by DIKTI.

Margana. (2013). Theoretical Justification of Bilingual Education Program. FLLT conference (pp. 772 - 773). Thailand: Thammasat University.

Margana. (2015, November). Establishing English-Indonesian Bilinguals in Indonesia : From Theory to Practice. RA Journal of Applied Research, 1(10), 372.

Matter, G. (2012, March 18). Why Billinguals are Smarter. New York: New York Edition.

Nasional.kompas. (2011, 10 17). Kompas. Nasional. Retrieved 10 24, 2018, from Nasional.Kompas:https://nasional.kompas.com/read/2011/10/17/14480782/RSBI.Cipt akan.Kasta.dalam.Pendidikan

Owens, R. (2012). Language Development : An Introduction. Boston, MA: Pearson.

Rakyat, K. (2013, Januari). Makamah Konstitusi Membubarkan RSBI. Yogyakarta.

Romaine, S. (1995). Bilingualism (Second Edition). Oxford, UK: Bassil Blackwell Ltd.

Santoso, D. (2006). Bilingual Education Program at Junior High school. Jakarta: Prenada Media. 
Serra, M. R. (2017). The Bilingual World: A Study on Bilingualism and its Cognitive Effects. Article, 6-11.

Undang-Undang Nomor 20 Tahun 2003 Tentang Sistem Pendidikan Nasional. (2003).

Walner,K. (2016). The Effects of Bilingualism on Language Development. Communication Sciences and Disorder : Student scholarship and Creative Works. 